\section{Sintering of silica-alumina granular materials and its catalytic properties}

AfANASY S. APKARIAN - Institute of Strength Physics and Materials Science SB RAS, National Research Tomsk State University - asaktc@ispms.tsc.ru

LÁszLó A. GÖMZE - Institute of Ceramics and Polymer Engineering,

University of Miskolc, Hungary, IGREX Engineering Service Ltd • femgomze@uni-miskolc.hu

JAMAL-ELDIN F. M. IBRAHIM - Institute of Ceramics and Polymer Engineering, University of Miskolc, Hungary • jamalfadoul@gmail.com

Sergei N. KULKOV - Institute of Strength Physics and Materials Science SB RAS, National Research Tomsk State University • kulkov@ms.tsc.ru

Érkezett: 2021. 06. 03. - Received: 03. 06. 2021. " https://doi.org/10.14382/epitoanyag-jsbcm.2021.19

\section{Abstract}

In this work was developed a filtering material, where a granular glass-ceramic with a catalytically active layer applied as a carrier. The main component of the pellet batch is alkaline glass which made it possible to intensify the processes of melting and foaming of the molten glass. It has been defined physical and technical characteristic of granules and obtained that its density smaller $300 \mathrm{~kg} / \mathrm{m}^{3}$ and strength under compression layers between 0.8-2.6 MPa. Taking into account the physical and technical characteristics of GCM granules, studies were carried out to determine the possibility of using them as filtering media with a catalytically active layer. This makes it possible not only to dispose of cullet, but also to create a highly efficient material from it, allowing water to be purified up to standards.

Keywords: foamed glass, granular ceramics, pores, catalytic properties, iron and manganese absorption

Kulcsszavak: habosított üveg, szemcsés kerámiák, pórusok, katalitikus tulajdonságok, vas és mangán abszorpció
\end{abstract}

\section{Introduction}

It is well known, the creation of new materials that provide high-quality water purification is important for human life. The water strategy developed in different countries defined the main directions of activities for the development of the country's water sector, ensuring sustainable water use, protection from the negative impact of contaminated water on humans.

For the purification of drinking water, physicochemical methods are widely used: sorption, coagulation, flotation, filtration and reagent methods. However, in areas where oil and gas production is intensively conducted, the content of iron, manganese and hydrogen sulfide in water exceeds the maximum permissible norms by 10-20 times. The filtering materials used in the different regions do not cope with water purification to standards and do not fully correspond to the solutions of the assigned tasks.

Now, the filtering media called "Manganese Greensand" is widespread - glutonite green sand, which is a natural material, covered with manganese compounds. It acts as a catalyst in the removal of soluble manganese and iron [1-3]. Manufacturing technology of "Manganese Greensand" includes pretreatment of sodium glauconite (NaZ) with a manganese chloride solution:

$$
\mathrm{Na}_{2} \mathrm{Z}+\mathrm{MnCl}_{2}<=>\mathrm{MnZ}+2 \mathrm{NaCl}
$$

The use of potassium permanganate in conjunction with these loads also allows you to remove hydrogen sulfide, oxidizing it to elemental sulfur, and partially, organic matter and biological pollution, ensuring water disinfection.
Afanasy S. APKARYAN

has PhD in Technical Sciences. He is head of Department and responsible for Nanotechnolog in the Institute of Strength Physics and Materials Science of the Russian Academy of Science since 2005. Candidate of Technical Sciences. Specialists in the field of thermal physics and ceramic production. Associate Professor in Tomsk State University of Control Systems and Radioelectronics.

László A. GÖMZE is establisher and professor of the Department of Ceramics and Silicate Engineering in the University of Miskolc, Hungary. He is author or coauthor of 2 patents, 6 books and more than 300 scientific papers. Recently, he is the chair of the International Organization Board of ic-cmtp6 the $6^{\text {th }}$ International Conference on Competitive Materials and Technological Processes and ecsiliconf2 the $2^{\text {nd }}$ European Conference on Silicon and Silica Based Materials.

Jamal Eldin F. M. IBRAHIM is a lecturer in the University of Bahri, Khartoum, Sudan, he graduated from University of Marmara, Istanbul, Turkey, Institute of Pure and Applied Sciences, Department of Metallurgical and Materials Engineering, for the time being, he is a PhD student in the University of Miskolc, Institute of Polymer and Ceramics Engineering, under supervision of Prof. L. A. Gömze

Sergei N. KULKOV is professor at the Tomsk State University and head of Department of Ceramics in the Institute of Strength Physics and Materials Science of the Russian Academy of Science since 1989. His research works are represented in 5 books, more than 150 articles, 18 patents and many International Symposiums and Conferences. At present he is head of department "Theory of Strength and Mechanic of Solids", member of "The American Ceramic Society" of "The APMI - International" and the DYM AT Society (France).

The main disadvantage of using Manganese Greensand is pretreatment with potassium permanganate solution, i.e. before the start of operation to obtain a layer of higher manganese oxides on the surface of the filtering material Manganese Greensand, the loading is pre-treated with a solution of potassium permanganate, or it is constantly dosed into water using a proportional dosing system (dosing pump) [3, 4].

As an effective material, this granular filter material is used to remove iron and manganese from water and the filter material is a catalyst that accelerates the interaction of Fe with oxygen dissolved in water, resulting in the formation of waterinsoluble iron III hydroxide. After that, iron in an insoluble form is retained in the layer of filter material, therefore the efficiency of water purification with filter is strongly influenced by the $\mathrm{pH}$ value $(\mathrm{PH})$. For effective removal of iron, it should be in the range of 6.8-8.5, for removal of manganese - more than 8 . If there is insufficient dissolved oxygen in the treated water, then aerators must be used in front of the filter and does not recommended to use for the purification of chlorinated water. Free chlorine significantly reduces both the service life of the filter material and its efficiency.

To purify water from manganese and iron, a filter material called MFO-47 has been developed and is also used, containing as a basis granular material of natural origin, burnt rock, on the surface of which a catalytically active layer is formed, 
consisting of a mixture of oxides $\mathrm{MnO}, \mathrm{Mn}_{2} \mathrm{O}_{3}$ and $\mathrm{MnO}_{2}$ [3, 5]. This method, based on the treatment of granular material with a solution of a modifying reagent containing manganese salts, does not allow efficient removal of hydrogen sulfide from water.

The aim of this work was to develop a filtering material, based on a granular glass-ceramic material (GCM) with a catalytically active layer applied as a carrier. This makes it possible not only to dispose of cullet, but also to create a highly efficient material from it, allowing water to be purified up to standards.

\section{Materials preparation and its properties}

The proposed composition of the charge for granules differs from those previously developed [6-8] in that the required chemical composition and structure of GCM granules are provided by using compositions including glass, a plasticizer low-melting clay, gasifier- coke and organic additives (sawdust).

The main component of the pellet batch is alkaline glass. When choosing the glass, it was assumed that the content of alkali metal oxides in them would make it possible to intensify the processes of melting and foaming of the molten glass.
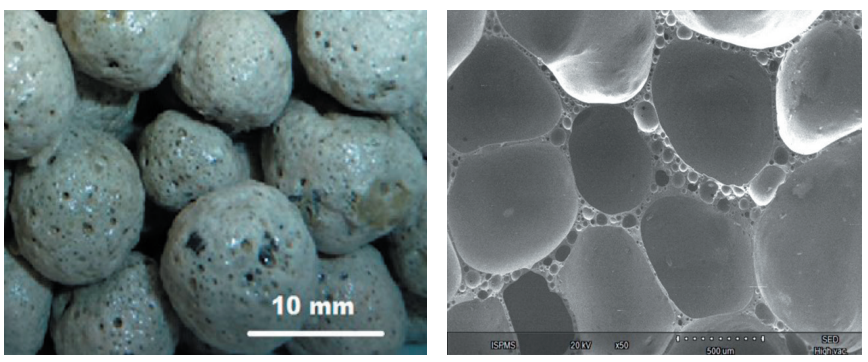

Fig. 1 GCM granules with a density of $260 \mathrm{~kg} / \mathrm{m}^{3}$ and its cross-section

1. ábra $260 \mathrm{~kg} / \mathrm{m}^{3}$ sürüségü GCM granulátum és annak keresztmetszete

The introduction of a plasticizer, low-melting clay, into the batch, contributes to a directed external effect on the glass during the firing period. The main tasks of adding a plasticizer are to increase strength and reduce water absorption. An important factor for the pore formation process is the swelling interval - the difference between the maximum possible firing temperature and the temperature of the beginning of clay swelling. The firing temperature must ensure sufficient softening and viscosity of the material; otherwise the gases formed during firing will freely escape, without material swelling.

A distinctive feature of the proposed composition of the charge for the production of GCM, in contrast to traditional compositions of foam glass, is the introduction of an organic component - sawdust (dispersed cellulose). The purpose of introducing organic additives into the charge is to increase the temperature of the raw granules and to heat the coke particles with the products of thermal decomposition of cellulose, contributing to the early process of gas formation from the combustion of coke, increasing the amount and pressure of gas in the pores of the foamed melt.

When using a plasticizer in the composition of the charge, the choice of the gasifier plays a decisive role. Since the plasticizer increases the viscosity of the molten glass, it is necessary to use such blowing agents, the decomposition products of which would have a pressure capable of foaming the molten glass during firing. When justifying the choice of the gas generator, the coincidence of the temperature intervals of the appearance of the melt of the required viscosity and the formation of the highest pressure of gaseous products were taken into account for this purpose coke was used in the experiments. The maximum firing temperature for raw granules is $830-850{ }^{\circ} \mathrm{C}$.

During the study, granules with a diameter of $0.8-10$ $\mathrm{mm}$ were used. As a result of research, it was found that to obtain porous GCM, it is necessary to use a plasticizer of the chemical composition: $\mathrm{SiO}_{2}-70-71 \% ; \mathrm{Al}_{2} \mathrm{O}_{3}-17-18 \% ; \mathrm{Fe}_{2} \mathrm{O}_{3}$ $5-6 \%$; $\mathrm{SO}_{3}-0.2-0.3$, in which illite, chlorite, hydromuscovite, montmorillonite and organic additives predominate, providing a large amount of $\mathrm{CO}$ at the initial stage of the formation of a porous amorphous-crystalline glass-ceramic system. When $\mathrm{CO}$ interacts with iron compounds, which are part of the plasticizer, and glass, iron carbide is formed with the release of $\mathrm{CO}_{2}$, which contributes to the intensive process of gas formation and the formation of a porous structure of granules. By changing the amount of plasticizer in the charge, the density of the granules can be varied from 200 to $300 \mathrm{~kg} / \mathrm{m}^{3}$, the thickness of the interpore partitions is from $0.07 \mu \mathrm{m}$ to 50 $\mu \mathrm{m}$, and the pore area in the granules is $0.10-0.72 \mathrm{~mm}^{2}$. The pore sizes and their location, the thickness of the glass-ceramic partitions and the glaze layer of the granules were examined under an optical microscope, Fig. 2.

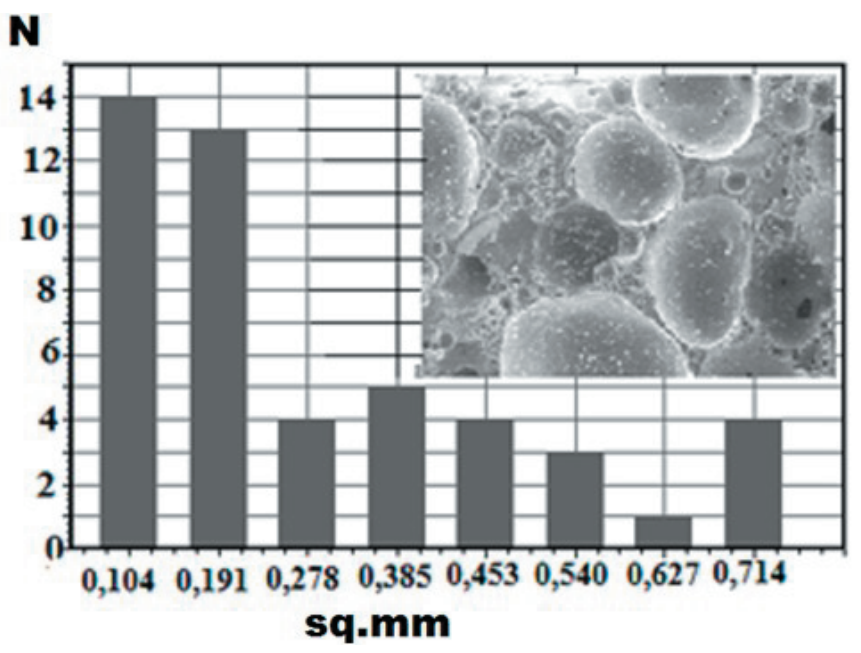

Fig. 2 Micrograph and size distribution of pores with a plasticizer content 10\%

2. ábra $10 \%$ lágyitó tartalmú pórusok mikroszerkezete és méreteloszlása

\begin{tabular}{ccccc}
$\begin{array}{c}\text { Density, } \\
\mathbf{k g} / \mathrm{m}^{3}\end{array}$ & $\begin{array}{c}\text { Thermal } \\
\text { conductivity, } \\
\mathrm{W} /\left(\mathrm{m}^{\circ} \mathrm{C}\right)\end{array}$ & $\begin{array}{c}\text { Strength } \\
\text { under } \\
\text { compression, } \\
\mathrm{MPa}\end{array}$ & $\begin{array}{c}\text { Temperature } \\
\text { operation, } \\
{ }^{\circ} \mathrm{C}\end{array}$ & $\begin{array}{c}\text { Water } \\
\text { absorption, } \\
\%\end{array}$ \\
\hline
\end{tabular}

Table 1 Physical and technical characteristics of GCM granules

1. táblázat GCM granulátumok fizikai és müszaki jellemzői 
As a result of research, granules with physical and technical characteristics are presented in Table 1 and Fig. 3.
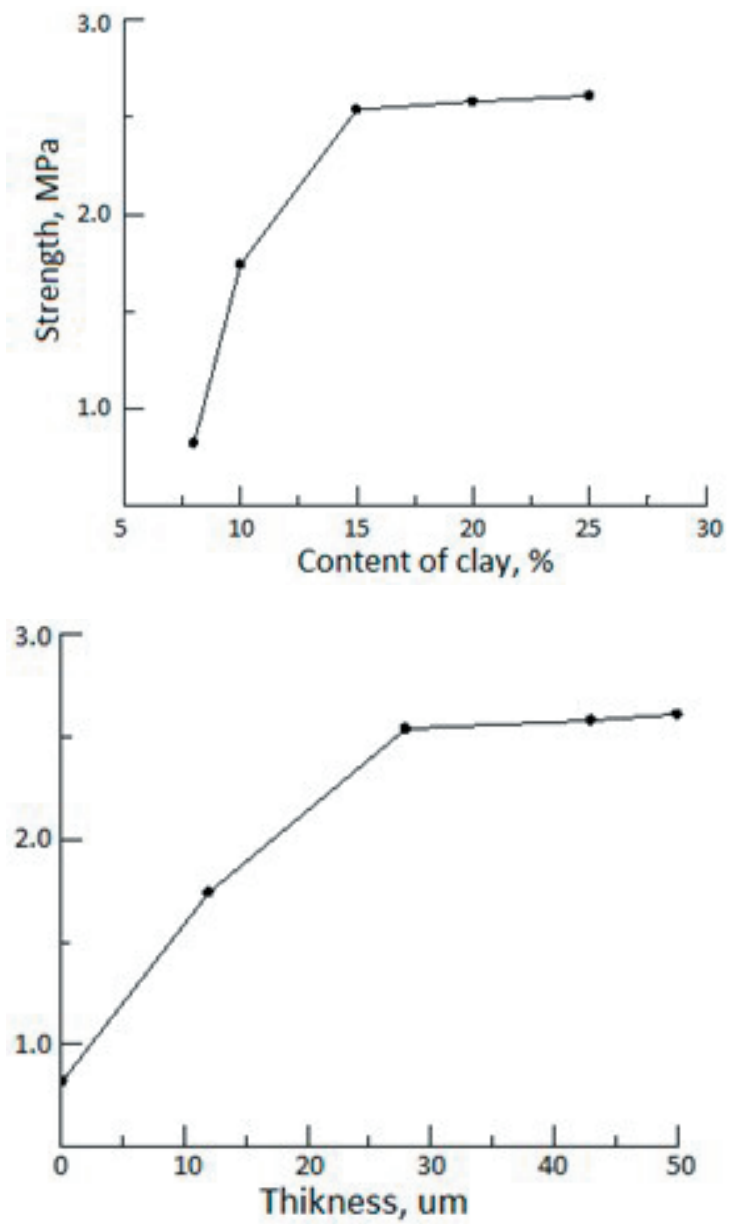

Fig. 3 Properties of GCM granules with a density of $260 \mathrm{~kg} / \mathrm{m}^{3}$

3. ábra A $260 \mathrm{~kg} / \mathrm{m}^{3}$ sürüségü GCM granulátumok tulajdonságai

\section{Catalytic properties of material and discussions}

Taking into account the physical and technical characteristics of GCM granules, studies were carried out to determine the possibility of using them as filtering media with a catalytically active layer.

The solution to this problem is achieved by sequential processing of granular material, natural origin, solutions containing manganese salts. First, the granules are treated in a solution containing divalent manganese salts, with a solution of potassium permanganate, and then with a solution of a reagent that promotes the reduction of manganese (VII) and the formation of a mixture of manganese oxide compounds on the surface of the granular material. This method of processing a filtering granular load (natural dispersed material) with modifying reagents containing manganese compounds of different valences makes it possible to obtain on its surface a complex of not only manganese oxide compounds, but also hydroxide ones. When implementing the proposed method on the surface of the filtering media received a mixture consisting of manganese hydroxide $\mathrm{Mn}(\mathrm{OH})_{2}$, and manganese oxides $\mathrm{Mn}_{2} \mathrm{O}_{3}, \mathrm{MnO}_{2}$ [9].
It should be noted that the granular material is pre-treated with an alkali solution. $\mathrm{NaOH}$ or $\mathrm{KOH}$ at a concentration of $10 \mathrm{~g} / \mathrm{l}$ is used as an alkali solution. The recovery of potassium permanganate is carried out by processing the material in a solution of $0.1-2.0 \%$ of a reducing agent. In this case, $\mathrm{pH} 8-12$ was maintained throughout the entire process of formation of the catalytic layer. During processing, air was blown and the solution was stirred.

Iron is in water in the form of a compound $\mathrm{Fe}\left(\mathrm{HCO}_{3}\right)_{2}$. When $\mathrm{Fe}\left(\mathrm{HCO}_{3}\right)_{2}$ interacts with the catalytically active layer of the granule, iron is precipitated in the form of iron hydroxide $\mathrm{Fe}(\mathrm{OH})_{3}$ according to the formula:

$$
\begin{gathered}
4 \mathrm{Fe}\left(\mathrm{HCO}_{3}\right)_{2}+3 \mathrm{MnO}_{2}+2 \mathrm{H}_{2} \mathrm{O} \rightarrow \\
4 \mathrm{Fe}(\mathrm{OH})_{3} \downarrow+\mathrm{MnO}+\mathrm{Mn}_{2} \mathrm{O}_{3}+8 \mathrm{CO}_{2} \uparrow .
\end{gathered}
$$

The results of studies of the filtering material based on GCM granules showed that with an increase in the filtration time, at a water speed of $1 \mathrm{dm}^{3} / \mathrm{min}$. and the volume of the passed water $100 \mathrm{dm}^{3}$, the iron content falls from 0.76 to $0.06 \mathrm{mg} / \mathrm{dm}^{3}$ (Fig. 4).

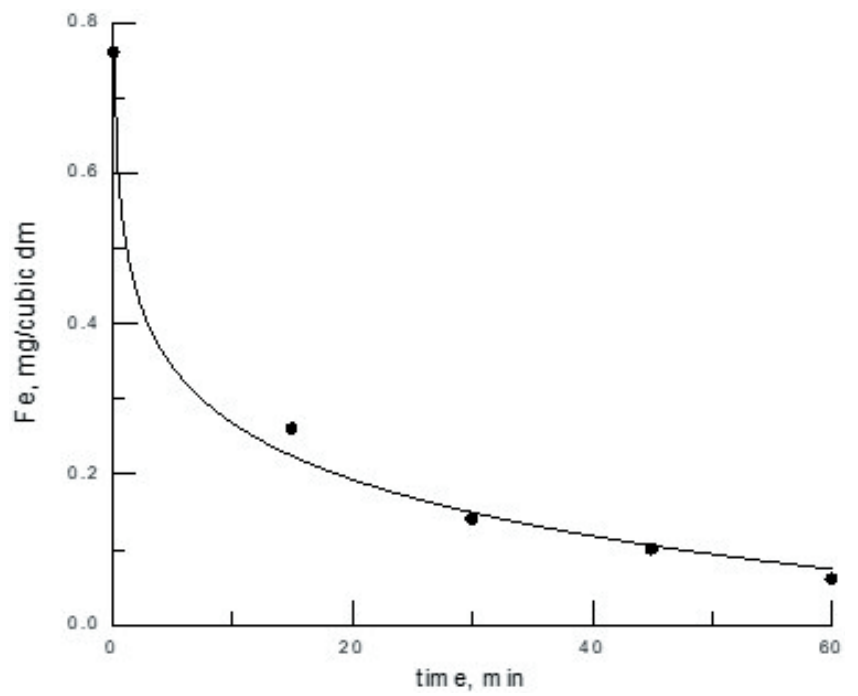

Fig. 4 Change in iron content vs. filtration time

4. ábra A vastartalom változása a szürési idö függvényében

It has been established $[2,10]$ that manganese oxides preprecipitated on the surface of GCM granules have a catalytic effect on the oxidation of manganese (II) ion by oxygen dissolved in water.

When filtering aerated water, oxygen dissolved in water is adsorbed on the surface of the granule and interacts with manganese ions to form a layer consisting of a negatively charged precipitate of manganese hydroxide $\mathrm{Mn}(\mathrm{OH})_{4}$, which adsorbs positively charged manganese (II) ions, forming an oxide manganese $\mathrm{Mn}_{2} \mathrm{O}_{3}[11]$ :

$$
\begin{aligned}
\mathrm{Mn}(\mathrm{OH})_{4}+\mathrm{Mn}(\mathrm{OH})_{2} & \rightarrow \mathrm{Mn}_{2} \mathrm{O}_{3}+3 \mathrm{H}_{2} \mathrm{O}, \\
2 \mathrm{Mn}_{2} \mathrm{O}_{3}+\mathrm{O}_{2}+8 \mathrm{H}_{2} \mathrm{O} & \rightarrow \mathrm{Mn}(\mathrm{OH})_{4} \downarrow .
\end{aligned}
$$

As a result, manganese (IV) hydroxide is again formed, which is involved in the oxidation process as a catalyst.

In water, a solution of hydrogen sulfide $\mathrm{H}_{2} \mathrm{~S}$ is a two-basic weak acid hydrogen sulfide. Acids are known to react with bases, basic oxides and salts, in this case, with $\mathrm{Mn}(\mathrm{OH})_{2}$. An increase in the efficiency of water purification from hydrogen sulfide occurs by the reaction:

$$
\mathrm{Mn}(\mathrm{OH})_{2}+\mathrm{H}_{2} \mathrm{~S}=\mathrm{MnS}+2 \mathrm{H}_{2} \mathrm{O} \text {. }
$$


Thus, granular glass-ceramic material as a carrier with a saturated catalytically active layer consisting of manganese oxides and hydroxides is capable of effectively removing iron, manganese, and hydrogen sulfide from water [1].

The advantage of the method is the production of hydroxide and manganese oxide compounds firmly adhered to the base on the surface of the filter medium at room temperature. The catalytically active layer, due to the adhesion caused by intermolecular interaction, is firmly fixed on the surface and is not washed off. Table 2 reflects a decrease in the efficiency of water purification from hydrogen sulfide with a decrease in manganese hydroxide in the mixture.

\begin{tabular}{cccc} 
№ & $\begin{array}{c}\text { Mn(OH })_{2} \text { content } \\
\text { on the surface of } \\
\text { granules, } \mathbf{g} / \mathbf{k g}\end{array}$ & $\begin{array}{c}\mathbf{H}_{2} \mathbf{S} \text { content in } \\
\text { source water, } \\
\mathbf{m g} / \mathbf{d m}^{3}\end{array}$ & $\begin{array}{c}\mathbf{H}_{\mathbf{2}} \mathbf{S} \text { content } \\
\text { in purified water, } \\
\mathbf{~} \mathbf{m} / \mathbf{d m}^{3}\end{array}$ \\
\hline 1 & 10 & 0,1 & 0,03 \\
\hline 2 & 9 & 0,1 & 0,033 \\
\hline 3 & 8 & 0,1 & 0,035 \\
\hline 4 & 7 & 0,1 & 0,040 \\
\hline 5 & 6 & 0,1 & 0,045
\end{tabular}

Table 2 The degree of efficiency of water purification from hydrogen sulfide with a decrease in the content of manganese hydroxide in the mixture

2. táblázat A hidrogén-szulfidból történő víztisztítás hatékonyságának mértéke a keverék mangán-hidroxid-tartalmának csökkenésével

A comparative study of the processes of sorption of sulfide ions on GCM granules was carried out under static conditions. Model solutions were prepared by diluting the S2 stock solution with a concentration of $100 \mathrm{mg} / \mathrm{l}$. The sorbent weighing $0.2 \mathrm{~g}$ was placed in a dry conical flask with a thin section with a volume of $250.0 \mathrm{ml}, 100.0 \mathrm{ml}$ of a model solution was added there (sorbent: solution ratio=1:500), stirred on a THYS2 universal vibration machine (Germany) for $60 \mathrm{~min}$, Then the solution was separated by decantation and the mass concentration of $\mathrm{S}^{2-}$ was determined according to $\mathrm{RD}$ 52.24.450-95 by the extraction-photometric method on a PE$5400 \mathrm{v}$ spectrophotometer. The equilibrium concentration of sulfide ions was determined according to the results of a "blank" experiment - a model solution of the same concentration, but without a sorbent to take into account the loss of $\mathrm{S}^{2-}$ due to the volatilization of hydrogen sulfide. The static exchange capacity (SEC) was calculated using the equation:

$$
S E C=V_{\text {solute }}\left(C_{\text {equilibr }}-C_{\text {concentr. }}\right) / m_{\text {corbent }}
$$

Table 3 shows that the concentration of hydrogen sulfide after sorption of GCM is less than that on the material - the prototype MFO-47, by 10-20 times. The static exchange capacity of the GCM is 2 - 2.7 times higher than the corresponding indicator for the MFO-47 material.

On Fig. 5 is shown the dependence of the static exchange capacity (SEC), $\mathrm{mg} / \mathrm{g}$, on the mass concentration of $\mathrm{S}^{2}$ (isotherm of sorption of sulfide ions) for the MFO-47 sorbents and GCM granules at $\mathrm{t}=23^{\circ} \mathrm{C}$. Experimental and industrial tests have established that the complex of compounds deposited on the surface of the GCM granules determines the high catalytic activity of the load in relation to various salts of iron, manganese and hydrogen sulfide dissolved in water.

\begin{tabular}{|c|c|c|c|c|c|c|}
\hline \multirow[t]{2}{*}{$\mathbf{N}$} & \multirow{2}{*}{$\begin{array}{l}\mathrm{C}_{s}{ }^{2 \cdot} \text { initial } \\
\mathrm{mg} / \mathrm{dm}^{3}\end{array}$} & \multirow{2}{*}{$\begin{array}{l}\mathrm{C}_{\mathrm{s}}{ }^{2 .} \text { equilibr } \\
\mathrm{mg} / \mathrm{dm}^{3}\end{array}$} & \multicolumn{2}{|c|}{ MFO-47 } & \multicolumn{2}{|c|}{ GCM } \\
\hline & & & $\begin{array}{l}\mathrm{C}_{\mathrm{s}}^{2 .} \text { concentr } \\
\mathrm{mg} / \mathrm{dm}^{3}\end{array}$ & $\begin{array}{l}\mathrm{COE} \\
\mathrm{mg} / \mathrm{g}\end{array}$ & $\begin{array}{l}\mathrm{C}_{\mathrm{s}}^{2 .} \text { concentr } \\
\mathrm{mg} / \mathrm{dm}^{3}\end{array}$ & $\begin{array}{c}\text { SEC } \\
\mathrm{mg} / \mathrm{g}\end{array}$ \\
\hline 1 & 0,10 & $0,015 \pm 0,002$ & $0,01 \pm 0,002$ & 0,0020 & $0,007 \pm 0,001$ & 0,0040 \\
\hline 2 & 0,30 & $0,20 \pm 0,020$ & $0,13 \pm 0,02$ & 0,0350 & $0,010 \pm 0,002$ & 0,0945 \\
\hline 3 & 0,40 & $0,37 \pm 0,020$ & $0,22 \pm 0,02$ & 0,0775 & $0,012 \pm 0,002$ & 0,1780 \\
\hline 4 & 0,80 & $0,69 \pm 0,040$ & $0,38 \pm 0,02$ & 0,1540 & $0,024 \pm 0,003$ & 0,3330 \\
\hline 5 & 1,00 & $0,90 \pm 0,050$ & $0,5 \pm 0,03$ & 0,1604 & $0,036 \pm 0,003$ & 0,4310 \\
\hline 6 & 1,20 & $1,17 \pm 0,060$ & $0,78 \pm 0,04$ & 0,1950 & $0,097 \pm 0,010$ & 0,5360 \\
\hline
\end{tabular}

Table 3 Static exchange capacity, SEC, of MFO-47 and developed GCM 3. táblázat Az MFO-47 és a kifejlesztett GCM statikus cserekapacitása, SEC

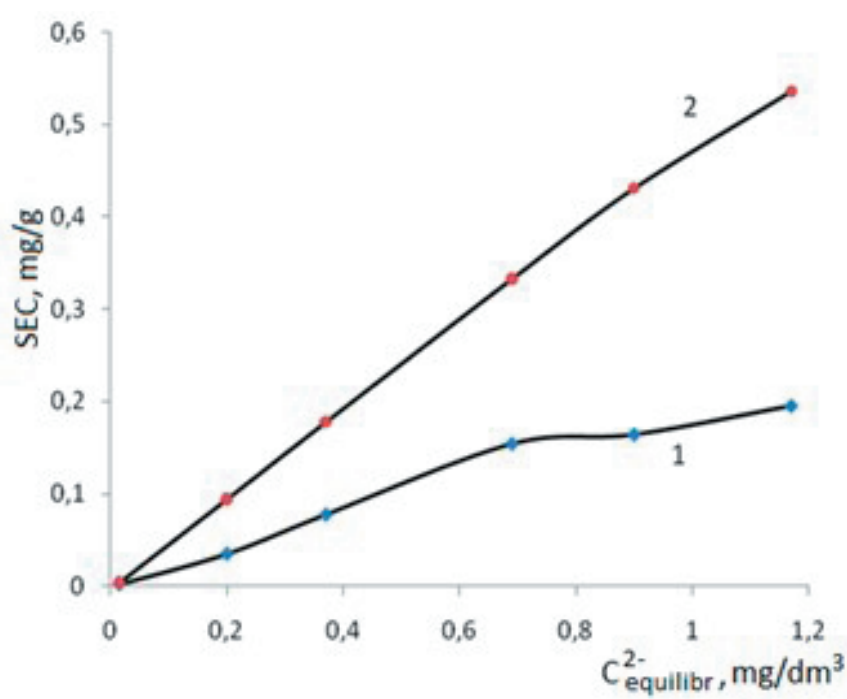

Fig. 5 Isotherms of sorption of sulfide ions on sorbents: curve 1 - MFO-47 and 2 GCM at $23^{\circ} \mathrm{C}$

5. ábra Szulfidionok szorpció izotermái a szorbenseken $23^{\circ} \mathrm{C}$-on: 1. görbe - MFO-47 és 2. görbe - GCM

It was experimentally established that a complex of compounds on the surface of granules causes high catalytic activity towards various salts of iron, manganese and hydrogen sulfide dissolved in water.

\section{Conclusions}

It has been found that on the surface of the base, glassceramic granules, after treatment with modifying reagents, a catalytically active layer was formed containing a mixture of manganese hydroxide $\mathrm{Mn}(\mathrm{OH})_{2}$ and manganese oxides $\mathrm{Mn}_{2} \mathrm{O}_{3}$ and $\mathrm{MnO}_{2}$.

It has been shown that oxides $\mathrm{Mn}_{2} \mathrm{O}_{3}, \mathrm{MnO}_{2}$ and hydroxide $\mathrm{Mn}(\mathrm{OH})_{2}$, obtained on the surface of glass-ceramic granules, make it possible to remove iron and manganese from water, reducing their content up to 15 times.

\section{Acknowledgments}

The work was performed according to the Government research assignment for ISPMS SB RAS, project FWRW2021-0005. The described article was carried out as part of the EFOP-3.6.1-16-00011 "Younger and Renewing University Innovative Knowledge City - institutional development of the University of Miskolc aiming at intelligent specialisation”. 


\section{References}

[1] Jean-Paul Duroudier (2017): Adsorption-Dryers for Divided Solids. Elsevier Ltd. p.296. https://doi.org/10.1016/C2016-0-00504-1

[2] Angelo Basile, Alfredo Cassano, Navin K. Rastogi (2015): Advances in Membrane Technologies for Water Treatment. Woodhead Publishing. p. 666 https://doi.org/10.1016/C2013-0-16469-0

[3] Berlin A. A., Wolfson S. A, Oshmyan V. G., Yenikolopyan N. S. (1990): Principles of creating composite materials. M.: Chemistry

[4] Ketov, A.A. (2001): An experience of reuse of glass cullet for production of foam structure material, Proc. Int. Symp. "Recycling and Reuse of Glass Cullet," March 19-20, 2001, Dundee, pp. 85-91.

[5] Apkaryan, A. and Khristyukov, V., Russian Patent \#2540741, 2014.

[6] Guloyan, Yu.A. (2003): Chemical reactions between components in the production of glass-forming melt, Glass Ceram., Vol. 60, Nos. 7-8, pp. 233-235. https://doi.org/10.1023/A:1027395310680

[7] Apkaryan, A.S., Kulkov, S.N., and Gömze, L.A. (2014): Foam glass ceramics as composite heat-insulating material, Épitöanyag - Journal of Silicate Based and Composite Materials, Vol. 66. No. 2, pp. 38-42. http://dx.doi.org/10.14382/epitoanyag-jsbcm.2014.8

[8] Apkaryan, A. and Khristyukov, V. (2014): Composite granular thermal insulation material-foam glass ceramic, Perspekt. Mater., No. 6, pp. $42-47$.
[9] Apkaryan A.S. (2014) Investigation of the Density of Granular FoamGlass Ceramic by Mathematical Modeling. Glass and Ceramics, Springer. Science + Business Media. New York. T. 71. № 5-6. C. 194-197.

[10] Kulkov S.N., Apkaryan A.S. (2018): Formation of Structure and Closed Porosity under High-Temperature Firing of Granules of Porous GlassCeramic Material. Inorganic Materials: Applied Research Vol. 9, No. 2, p.286.

[11] Apkaryan A.S., Gubaidulina T.A., Kaminskaya O.V. (2015): Foam-Glass Ceramic Based Filtering Material for Removing Iron and Manganese from Drinking Water. Glass and Ceramics, Springer. Science + Business Media. New York. T. 71. № 11-12. C. 413 - 416.

Ref.:

Apkarian, Afanasy S. - Gömze, László A. - Ibrahim, Jamal-Eldin F. M. - Kulkov, Sergei N.: Sintering of Silica-Alumina Granular Materials and its Catalytic Properties Építőanyag - Journal of Silicate Based and Composite Materials, Vol. 73, No. 4 (2021), 132-136. p. https://doi.org/10.14382/epitoanyag-jsbcm.2021.19

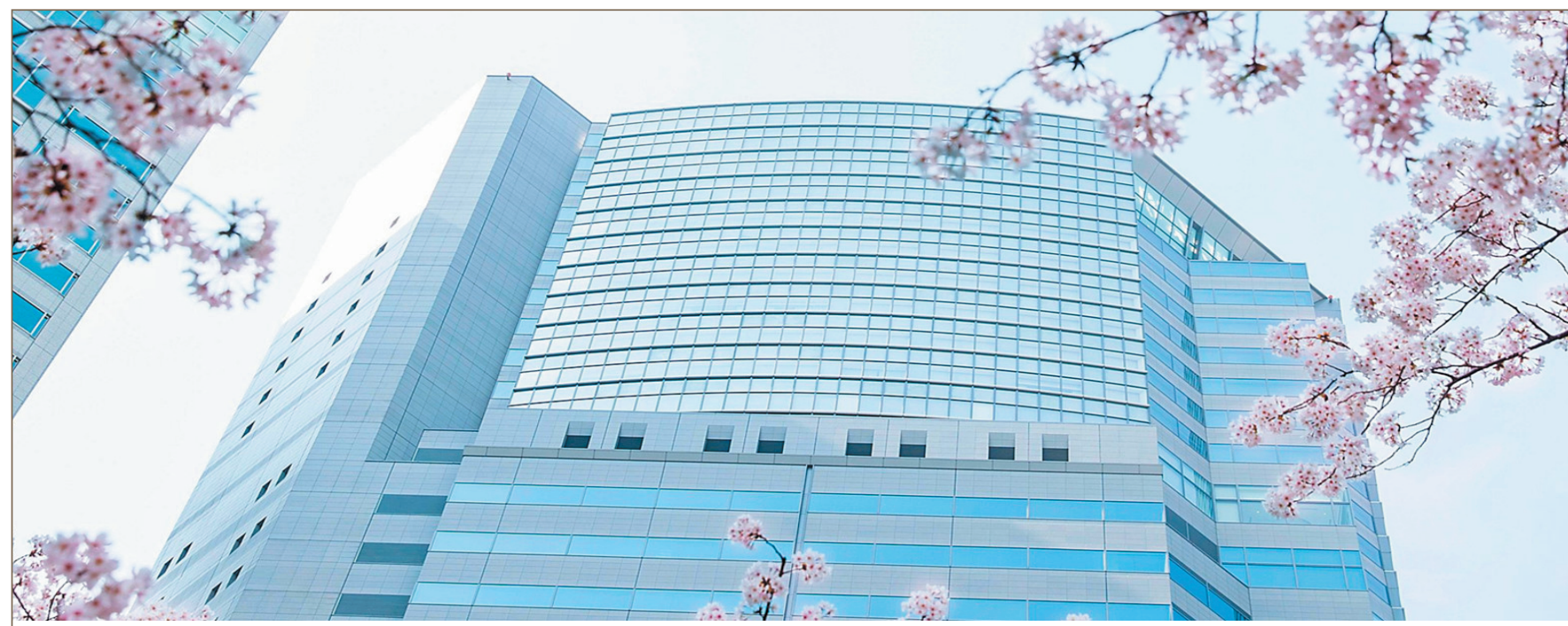

\section{(V) $\frac{I C E C E}{2022}$}

\section{$20229^{\text {TH }}$ INTERNATIONAL CONFERENCE ON \\ GEOLOGICAL AND CIVIL ENGINEERING TOKYO, JAPAN, JANUARY 20-22, 2022}

The aim of the 2022 9th International Conference on Geological and Civil Engineering (ICGCE 2022) is to provide a platform for researchers, engineers, academicians as well as industrial professionals from all over the world to present their research results and development activities in Geological and Civil Engineering.

ICGCE 2022 provides opportunities for the delegates to exchange new ideas and application experiences face to face, to establish business or research relations and to find global partners for future collaboration. 